\title{
Digital learning: Realities and Perspectives of a New Trend
}

\author{
Tatyana V. Shushara ${ }^{1 *}$, Yuliya D. Ustinova ${ }^{2}$,Elena A. Braslavskaya ${ }^{3}$, Yuliya A. Lopashova ${ }^{2}$, \\ and Viktor I. Plitka ${ }^{1}$ \\ ${ }^{1}$ Crimean V.I. Vernadsky Federal University, Humanities and Pedagogics Academy (branch) in Yalta, \\ Yalta, Russia \\ ${ }^{2}$ Crimean Republican Institute of postgraduate pedagogical education, Simferopol, Russia \\ ${ }^{3}$ Sevastopol State University, Sevastopol, Russia
}

\begin{abstract}
The relevance of the research is determined by the need to study the problem of education digitalization in order youth to self-identify themselves in the modern society, as well as by insufficient development of theoretical, content and scientific aspects of this issue. The article is to highlight the current state and future prospects of education digitalization. The purpose of the article is to study the features of education digitalization at the current stage and to define its perspectives. The main research methods used are theoretical ones, since they provide the opportunity to consider the modern problem of education digitalization as a holistic process and to reveal its future prospects. The article presents the analysis of the current state of education digitalization and future prospects of this process. The overview of the research issue is oriented to the study of education digitalization prospects in order youth to self-identify themselves in the modern society. The research is also focused on the elaboration of methodological recommendations concerning this problem.
\end{abstract}

\section{Introduction}

Modern society is characterized by global dynamic transformations in every area of human endeavour connected with the fourth industrial revolution [1]. This state of affairs obligates the education system to react quickly to new important requirements which appearsystemically. Digitalizationof learning environment is becoming more and more common nowadays, since it gives the possibility to create individual educational trajectories. It also develops continuing education, the purpose of which is to teach new specialists in the field of economy, who possess new general and professional competences.

The current stage of social transformations in the field of digitalization is set out by the following documents: Decree of the President of the Russian Federation of 9 May 2017 №203 "Strategy of the Information Society Development in the Russian Federation for 2017 2030" [2], the National Program "Digital Economy of the Russian Federation" [3], the National Project "Education" [4]. These documents allow creating modern safe digital environment the purpose of which is to ensure

\footnotetext{
*Corresponding author: tanya.yalos@mail.ru
} 
competitive high qualityaccessible education of all types and levels.

Digital technologies are the integral part of our life and such concepts as "cyberspace", "cybersocium", "cybersociality" [5] are our new reality, and education has to adapt to it introducing digital education.

Thus, the fourth industrial revolutionfacilitated the human society transition into cyber reality and transformation of traditional education into digital one.

\section{Methods}

The following research methods were used: theoretical (analysis, synthesis, comparison, systematization of facts which reflect the process of education environment digitalization); searching for specific information (for collecting, selecting, processing and analyzing the data concerning modern scientific investigations which highlight the research problem).

\section{Results}

\subsection{Who is the addressee of digitalization of the educational environment?}

According to the "generation theory" today we deal with the generation" $Z$ ", the so-called "digital" generation [6]. The basic characteristics of this generation are the following: digital addiction, rapid intellectual development, susceptibility to informational influence, consumerism, developed clip thinking, low attention span, developed short-term memory, perceptual disorder, Attention-Deficit Hyperactivity Disorder and hyperactivity, autism tendencies, infantilization, blurring of life principles and guidance. Thus, digitalization of educational environment is focused on that category of people, as well on those who understand the importance and necessity to analyze and use the cutting-edge scientific developments fortheir professional and career growth.

\subsection{Challenges and risks of digital learning}

There are a number of digital learning challenges and risks that educational system should take into consideration. Some of them are the following: lack of digital learning psychological and pedagogical theory, contradictions in terms of the notions information and knowledge as a part of sign system and person substructure, lack of communication "teacherstudent", risks of speech and mental activity worsening, absence of the concept "upbringing", socialization weakening, reducing of social contacts and communication that leads to loneliness [7], impossibility toshape systematic worldview[8],weakening of imagination and creative thinking, nomophobic behavior - the fear of being without a mobile device (or any other gadget) [9].

\subsection{Current state of the educational environment digitalization}

The year 2020 made adjustments to educational environment digitalization. Coronavirus disease COVID-19 pandemic and offered by the Government measures to prevent spread of the virus transformed traditional educational system into distance learning educational system with the help of digital learning and distance education technologies. The result of these measures is the large-scale online education on different digital platforms.

At the beginning of digital learning the following problems were identified: distance learning websites were overloadedand stopped working,partial lack of computer equipment 
for education and bad Internet connection, teachers were not ready for digital learning in terms of teaching and technical aspects [10].

Then psychological discomfort was identified which showed that psycho-pedagogical supportshould have been provided to learners, teachers and parents [11].

Independent research made with the help of digital media (messengers - Skype, Viber, Discord, WhatsApp, Telegram, social networks - Facebook, VK, Odnoklassniki) showed a number of problems. We surveyed 1318 parents and 301 students. The overall number of respondents was 1619 persons.

To assess the state of education digitalization we conducted a survey among both categories of respondents. Answers to the question: "How many hours do you / your children spend on a computer during distance learning?" are shown in the table 1. For illustrative purposes, age categories are given according to the levels of education.

Table 1. Amount of time spent on a computer during distance learning

\begin{tabular}{|c|l|c|c|c|}
\hline \multirow{2}{*}{$№$} & \multirow{2}{*}{ Level of education } & \multicolumn{3}{|c|}{ Amount of time, hours } \\
\cline { 3 - 5 } & & $\min$ & $\max$ & Optimal time \\
\hline 1. & Primary education & 3 & 5,5 & 0,75 \\
\hline 2. & Basic education & 5 & 6,5 & 1,5 \\
\hline 3. & Secondary education & 6,5 & 8 & 2,15 \\
\hline 4. & Students & 5 & 8,5 & - \\
\hline
\end{tabular}

The results in the table 1 show that the minimum amount of time for primary level educationis 4 times greater [12] than the optimal time, while maximum amount of time is 6 times greater than the optimal time. We can also observe that for learners of basic and secondary educationminimum amount of time spent on a computeris 3 times greater, and the maximum amount of time is 4 times greater. The data obtained indicate that there is no any control over the time spent by learners when digital learning takes place.

One more problem revealed in this research is the ill-health of digital learning participants. Answers to the question: "What is the impact of digital technologies on human health?" are shown in table 2.

Table 2. The impact of digital technologies on human health

\begin{tabular}{|c|l|c|c|}
\hline № & \multicolumn{1}{|c|}{ Criterion } & Parents, persons, \% & Learners, persons, $\%$ \\
\hline 1. & Negative impact & 54 & 27 \\
\hline 2. & Positive impact & 18 & 16 \\
\hline 3. & No impact & 22 & 53 \\
\hline 4. & I don't know & 6 & 4 \\
\hline
\end{tabular}

We think the results given in this table to be very interesting, since $54 \%$ of learners' parents admit negative impact of digital technologies, while $53 \%$ of learners observe no impact of digital technologies on human health. Whereas $18 \%$ of parents and $17 \%$ of learners point out that digital technologies have positive impact.

On the basis of the responses, main digital learning problems were grouped according to the respondents' category.

Table 3. Main digital learning problems

\begin{tabular}{|l|l|c|c|}
\hline № & \multicolumn{1}{|c|}{ Problem } & $\begin{array}{c}\text { Respondents' } \\
\text { category }\end{array}$ & $\begin{array}{c}\text { Amountofpersons, } \\
\%\end{array}$ \\
\hline 1. & Lack of live qualified teaching support & Parents & 74 \\
\hline 2. & Lack of educational process & Parents & 31 \\
\hline 3. & Greater training time & Parents & 39 \\
\hline
\end{tabular}




\begin{tabular}{|l|l|c|c|}
\hline & \multicolumn{1}{|c|}{ Learners } & 67 \\
\hline 4. & $\begin{array}{l}\text { Helplessness of the primary } \\
\text { educationlearners when digital learning } \\
\text { takes place }\end{array}$ & Parents & 19 \\
\hline 5. & $\begin{array}{l}\text { Socialization of children with limited } \\
\text { abilities }\end{array}$ & Parents & 4 \\
\hline
\end{tabular}

The results in table 3 show that they were learners who faced great challenge during digital learning. Survey resultsgive us reason to believe that digital learning should be introduced as a part of traditional education.

It is important to note, however, that all respondents point out at positive impact of digital learning: in-depth self-study possibility $-42 \%$, preparing to be a member of cybersocium$37 \%$, future professional career training $-51 \%$, developing abilities necessary for new professions of a "digital" society $-32 \%$, availability of modern technologies $-71 \%$.

\subsection{Digital learning perspectives}

Digital learning provides an opportunity for representatives of $\mathrm{Z}$ generation to improve such skills as: multilanguage and multiculturalism, multidisciplinary communication, project management, ability to work under high pressure and in rapidly changing conditions, control of attention, creativity, work with artificial intelligence, complex computer-aided systems operation, IT-solutions programming [13], which are needed for specialists of "digital" society.

Digital learning will be evolved when the following requirements are met: educational organizations will be supplied with digital devices of new generation, with sufficient software, and systems for the objective evaluationand feedback systems; teacher training and professional development of teachers; supplying teachers with digital study materials, with digital educational games, and simulators; use of artificial intelligence technologies allowing to modify education process according to the individual characteristics of learners.

\section{Discussion}

The study of psychological and pedagogical literature showsthat there are no any special researches in the field of large-scale digital learning. Challenges, risks and prospects of digital learning were examined by A.A. Verbitskii [7].

The notion "digital learning" is viewed as pattern, principles and mechanismsof acquisition of subject knowledge, skills, abilities, competencies while using wide range of information technologies [7].

The issue of digital learning is studied by the pedagogical science. Thus, M.E. VaindorfSysoeva, E.V. Filimonova, V.A. Larionova, G.A. Baklanova examined the problem of teacher training in the context of digital learning. A.I. Zimina examined how to use digital technologies at the lessons of chemistry, M.A. Petrova - at the lessons of physics, A.I. Krylov -in science. I.E. Aleksandrova studied the problem of hygienic digital educational process at school lessons. D.A. Semenova analyzed the problem of digital educational media resources utilization to develop cognitive activities of the learners with cerebral palsy with the help of music.

\section{Conclusion}


Thus, digitalization of educational environment, in general, and digital education, in particular, are the integral part of modern education. The process of education transition to digital learning is complex and multi-faced, but it is necessary in the current context of the fourth industrial revolution. However, this process should be implemented on a step-by-step basis not only from the standpoint of necessary technical equipment, but also professional training and retraining of the teaching stuff, methodological support of digital education.

The materials of the article can be useful for teachers of educational organizations, educators, teacher trainers, parents, who are interested in the problem of digital learning and digitalization of educational environment.

The research revealed the problems which require newnon-standard solutions such as: to continue providing early career guidance of learners in "digital" society, to develop new methodologies of professional self-identification of a person with the help of foresight technologies; to develop new digital study materials at all levels of education.

\section{Recommendations}

The article may be useful for experts and directors of the centres involved in digital learning, professional stuff members of educational organizations; learners who choose their future career and parents.

\section{References}

1. W. MacDougal, Industry 4.0 Smart Manufacturing for the Future (GTAI, 2014) Available at: https:/www.gtai.de/gtai-en/invest/service/publications/industrie-4-0germany-market-report-and-outlook-64602

2. Decree of the President of the Russian Federation №203, "Strategy of the Information Society Development in the Russian Federation for 2017 - 2030”, 9 May (2017) Available at: http://kremlin.ru/acts/bank/41919

3. The National Program "Digital Economy of the Russian Federation" Available at: https://digital.gov.ru/ru/activity/directions/858/

4. The National Project "Education" Available at: https://edu.gov.ru/national-project/

5. O.I. Voinova, V.A. Pleshkov, Homo Cyberus 1(4), (2018)

6. Generation $\mathrm{Z}$ psychological aspects (2016) Available at: http://mansauroki.blogspot.com/2016/04/z_12.html

7. A.A. Verbitskii, Homo Cyberus 1(6), (2019)

8. Digitalization of education (interview with S.A. Beshenkov) Available at: http://press.tstu.ru/index.php/aktualnoe-intervyu/2345-tsifrovizatsiya-obrazovaniya

9. Digital education (National education resources fund) Available at: https://nro.center/wp-content/uploads/2020/01/cifrovizacija-obrazovanija.pdf

10. Targeted assistance in the form of computers for education was provided to more than 220 learners and teachers (2020) Available at: https://edu.gov.ru/press/2408/bolee-220tysyach-shkolnikov-i-uchiteley-poluchili-adresnuyu-pomosch-v-vide-kompyuternoytehniki-dlya-obespecheniya-obrazovatelnogo-processa-l

11. Guidelines for psychological service staff in the education system with regard to the spread of Coronavirus disease (COVID-19) Available at: https://vestnik.edu.ru/uploads/files/e5ea7a5ad8fd7b1e207aa2fc74dc484f.pdf 
12. Methodical recommendations for efficient lesson organizing with the help of digital learning and distance education technologies (2020) Available at: https://docs.edu.gov.ru/document/3fc1af630afb644c0bed75ee27f0c020/

13. D. Varlamova, D. Sudakov, The atlas of new professions 3.0 (Intellectual literature, Moscow, 2020) 